\title{
Farm nitrogen flows of four farmer field schools in Kenya
}

\author{
Christy L. van Beek · Davies D. Onduru •
}

Louis N. Gachimbi · André de Jager

Published online: 18 October 2008

(C) Springer Science+Business Media B.V. 2008

\section{Erratum to: Nutr Cycl Agroecosyst (2008) \\ DOI 10.1007/s10705-008-9199-6}

Unfortunately the second author's name had been misspelled. The correct version is Davies D. Onduru and not Davies D. Onduro as published.

The online version of the original article can be found under doi:10.1007/s10705-008-9199-6.

C. L. van Beek ( $\square)$

Alterra, Wageningen University and Research Centre,

Wageningen, The Netherlands

e-mail: christy.vanbeek@wur.nl

D. D. Onduru

ETC East Africa, Nairobi, Kenya

L. N. Gachimbi

Kenya Agricultural Research Institute, Nairobi, Kenya

A. de Jager

LEI, Wageningen University and Research Centre,

Den Haag, The Netherlands 